\title{
Labour
}

Journal of Canadian Labour Studies

Le Travail

Revue d'Études Ouvrières Canadiennes

\section{Marian Jago, Live at the Cellar: Vancouver's Iconic Jazz Club and the Canadian Co-operative Jazz Scene in the 1950s and '60s}

\section{Eric Fillion}

Volume 85, printemps 2020

URI : https://id.erudit.org/iderudit/1070916ar

DOI : https://doi.org/10.1353/llt.2020.0015

Aller au sommaire du numéro

Éditeur(s)

Canadian Committee on Labour History

ISSN

0700-3862 (imprimé)

1911-4842 (numérique)

Découvrir la revue

Citer ce compte rendu

Fillion, E. (2020). Compte rendu de [Marian Jago, Live at the Cellar: Vancouver's Iconic Jazz Club and the Canadian Co-operative Jazz Scene in the 1950s and '60s]. Labour / Le Travail, 85, 302-304. https://doi.org/10.1353/ltt.2020.0015 d'utilisation que vous pouvez consulter en ligne. 
porters as historical agents, who engaged in persistent political activism. He details how Black porters established their own unions, the first in 1917 when the Winnipeg-based Order of Sleeping Car Porters was formed. Then in 1939 Black porters sent a letter to Asa Philip Randolph, head of the Brotherhood of Sleeping Car Porters in the United States and prominent Black civil rights activist, asking for his assistance in mobilizing porters to join the BSCP. The union for Black railway employees became certified in Canada on May 18, 1945. The BSCP operated six divisions that served its Black members across Canada until 1978. The union negotiated contracts with the railway companies that resulted in some improvements and benefits in the collective agreement for Black porters. Changes included better working conditions, sleep breaks, and fairer and more transparent disciplinary measures. Other gains included pay increases, overtime pay, paid vacation, and the ability to place name plaques in sleeping cars so that passengers would know their names.

They Call Me George explores the personal lives and activism of a number of porters including Bromley Armstrong, Stanley Grizzle, Harry Gairey, Cottrell Lawrence Dellums, Charles Ernest Russell, and Donald Moore who played a role in the formation of the BSCP and in the protest trip to Ottawa that influenced a new immigration policy that relaxed its xenophobic practices and became the basis for the points-based system. Foster interviewed surviving porters and drew on a variety of archival sources including newspaper articles, parliamentary speeches, government records, and trade union documents to chronicle their experiences.

Foster contends that Black train porters are deserving of recognition for their vision of a Canadian state that was multicultural and inclusive and for their active role in helping to make that ideal a reality, a case that he carefully lays out in the book. They Call Me George is valuable reading for students of Black Canadian studies, Canadian history survey courses, and courses in Canadian labour history and immigration.

Natasha Henry

York University

\section{Marian Jago, Live at the Cellar: Vancouver's Iconic Jazz Club and the Canadian Co-operative Jazz Scene in the 1950s and '60s (Vancouver: UBC Press 2018)}

LIVE AT THE CELLAR adds depth and resonance to the Canadian jazz soundscape by decentering the two cities most commonly associated with this music north of the border with the United States: Toronto and Montreal. In this book, Marian Jago, lecturer at the University of Edinburgh, examines the burgeoning scenes that developed around artist-run clubs in Vancouver (The Cellar, Black Spot, and Flat Five, among others), Edmonton (Yardbird Suite), Calgary (Foggy Manor), and Halifax (777 Barrington Street) from the mid-1950s to the late 1960s. The Cellar occupies centre stage in this social history of youth culture and jazz cooperatives, because of its significance as a cultural hub for musicians and non-musicians alike as well as its role in paving the way to a pan-Canadian scene rooted in regional networks. The book's accessible prose and lively narrative, augmented with the voice of many protagonists, aims to speak to a wide readership. In the process, it provides substance to the symbolic importance of the scenes it discusses while enriching our understanding of the transnational circulation of jazz as both a social practice and an art form. 
Divided into three parts, Live at the Cellar begins with the theoretical framework that informs the author's study of jazz cooperatives; namely, the concept of "scene," which is deployed here to locate and describe "the essential human relationships and social structures that enable particular localized forms of socio-cultural activity ... to occur." (15) Jago then discusses the local political context (from inadequate west-east transportation infrastructure to timeworn post-prohibition legislation) that favoured the emergence of unlicensed bottle clubs, a type of social venue that inspired Vancouver jazzophiles in their efforts to combat relative geographical isolation through music. Part 2 contains four chapters, all of which deal nearly exclusively with The Cellar: its mission, membership, modes of operation, and meaning as a place of encounters and creation. Considering the importance accorded to that venue, Part 3 could have served as an effective epilogue since its sole chapter takes readers on the road, heading east from Edmonton to Calgary and Halifax to juxtapose these cities' scenes against those of Montreal and Toronto. Careful not to overstate her point about the pan-Canadian nature of early jazz cooperatives, the author defines these initiatives as incubators that developed somewhat synchronously due to the music's growing appeal as a "shared and immediate experience" that could foster "self-reliance and vibrancy" in artist communities across postwar Canada. (248)

Jago's use of the concept of "scene," which she borrows from the fields of cultural sociology (Andy Bennett) and communications studies (Will Straw), is a judicious one in that it helps delimit the sites, identify the historical actors, and reveal the interactions (local, translocal, and virtual) that allowed artist-run cooperatives to thrive. As a case study,
The Cellar opens a window into the inner workings of a musically imagined community with boundaries of its own. It is here that the distinction between "space" (the physical site itself) and "place" (the symbolic and socio-cultural representation of the scene environment) finds its clearest expression. Although Jago eschews class as a category of analysis, she does examine the performative and constitutive effects of jazz cooperatives on musicians' and audiences' self-perception and sense of belonging. A socially constructed marker of difference, race inevitably factors into this story, though the question of whiteness in jazz - tied up here with the question of cultural appropriation - appears insufficiently problematized in the book. As for the gendered dimension of the Vancouver scene, from the articulation of androcentric discourses to the performance of heteromasculinity, Chapter 4 discusses it at length, but readers seeking a more trenchant analysis will need to browse through the endnotes where the author interrogates the "entrenched notions of gender" and the "performance of hegemonic masculinity" that informed some of the programming at The Cellar.

Jago's decision to focus on that venue derived, in part, from the fact that she had access to an abundance of sources (textual, audio, and iconographic), which she complemented with more than sixty interviews. Live at the Cellar is therefore also an oral history of the Vancouver scene. The topical interviews that the author conducted offer insights about the internal politics of cooperative endeavours. This material also constitutes a well of anecdotes that add colour to the stories told in the book. That said, the overuse of block quotations - accompanied inevitably by repetition and discrepancies between accounts - hinders the flow of the overall narrative at times. The episode where the renowned African American 
bassist and composer Charles Mingus got into an altercation with a member of the BC Lions football team is a good example. Quoting at length, Jago contrasts subjective recollections to implicitly illustrate how memory functions as a mechanism for situating oneself in time and in place. She subsequently explains: "[R]aised consistently as a point of reference by interviewees, [Mingus's stay at The Cellar] served as a tool for recognition ... and as a point of mutual experience that still ... separates those who were part of the scene from those who were not." (182)

Published through UBC Press, this study on the development of Canadian jazz is a valuable addition to a growing corpus of works that trace their origins to the 1980s when Mark Miller and John Gilmore published Jazz in Canada: Fourteen Lives (Toronto: University of Toronto Press, 1982) and Swinging in Paradise: The Story of Jazz in Montreal (Montreal: Véhicule Press, 1989), respectively. If the latter provided the incentive for the establishment of a jazz collection at Concordia University, an exceptional repository of oral interviews and archival documents with no parallels in Canada, one can hope that Live at the Cellar will inspire the creation of a similar repository for Vancouver and British Columbia. By bringing to the fore artist-run cooperatives in Calgary, Edmonton, and Halifax, Jago also ultimately makes the case that these cities have jazz histories worth pursuing. Her research thus lays some of the much-needed groundwork for the development of new perspectives on jazz in Canada.

ERIC Fillion

University of Toronto

\section{Graham D. Taylor, Imperial Standard: Imperial Oil, Exxon, and the Canadian Oil Industry from 1880 (Calgary: University of Calgary Press 2019)}

IN IMPERIAL STANDARD, Graham D. Taylor reconstructs the rich, transnational history of the Imperial Oil Company from 1880 to the present day. For most of its history, Imperial was the largest oil company in Canada and one of the most successful corporate entities in the country. Despite its incalculable significance for Canadian energy history, there is practically no scholarly work on the Imperial Oil Company; James Laxer and Ann Martin's 1976 monograph assessing Imperial's impact on the Canadian economy, and several books and articles published by the company are the rare exceptions. Perhaps not surprisingly, the large American oil companies and their histories have a significant body of literature. Taylor's study thus fills a longstanding gap in the literature on Canadian oil history and is particularly welcome at this critical moment in the country's energy trajectory.

Taylor is a business historian whose work focusses on the growth of multinational corporations during the late nineteenth and twentieth centuries. In Imperial Standard, Taylor makes his first book-length foray into the Canadian oil and gas industry, which he asserts was "arguably as important for the nation's economic development in the twentieth century as was the Canadian Pacific Railway in the nineteenth century and the Hudson's Bay Company in the years before Confederation." (3) The central thesis of the book is that over the past 140 years the Canadian oil and gas industry played a foundational role in the social, political, and economic life of Canadians and, more specifically, that Imperial was a corporate leader in the unfolding of the age of oil both in Canada and around the world. 